\title{
Medial Antebrachial Cutaneous Nerve: Anatomical Relationship with the Medial Epicondyle, Basilic Vein and Brachial Artery
}

\author{
Nervio Cutáneo Antebraquial Medial: Relación Anatómica \\ con el Epicóndilo Medial, Vena Basílica y Arteria Braquial
}

Aomjai Damwan*; Sithiporn Agthong*; Chavarin Amarase*;
Pattarapol Yotnuengnit*; Thanasil Huanmanop* \& Vilai Chentanez*

DAMWAN, A.; AGTHONG, S.; AMARASE, C.; YOTNUENGNIT, P.; HUANMANOP, T. \& CHENTANEZ, C. Medial antebrachial cutaneous nerve: anatomical relationship with the medial epicondyle, basilic vein and brachial artery. Int. J. Morphol., 32(2):481-487, 2014.

SUMMARY: Medial antebrachial cutaneous nerve (MACN) courses in the medial arm to provide sensory innervation to the medial forearm. Its anatomy has been partly described since data regarding its branching pattern and distances to adjacent landmarks are still lacking. The purpose of this study was to provide morphometric anatomy of the MACN with comparisons between sides and sexes. Ninety-six upper extremities from 26 males and 22 females were dissected. We found that up to 5 branches of MACN pierced the deep fascia with the maximum of 4 reaching the interepicondylar line (IEL). Presence of 2 and 3 branches was found in the majority of cases (> 80\%). The distances from these branches to the landmarks varied considerably. In case of no branch, the mean distances to the medial epicondyle (ME) and brachial artery (BA) were approximately $1.5 \mathrm{~cm}$ while those to the basilic vein (BV) were $0.7 \mathrm{~cm}$ in both sexes. Regardless of the branching pattern, the MACN could pass over or close (within $0.5 \mathrm{~cm}$ ) to the ME, BV and BA. Asymmetry in the branching pattern was found in $50 \%$ of specimens. Sex but not side differences were observed in some measurement parameters. These data are crucial for not only localizing the MACN during nerve block and graft harvest but also avoiding the nerve injury during surgical procedures.

KEY WORDS: Medial antebrachial cutaneous nerve; Anatomy; Medial epicondyle; Basilic vein; Brachial artery

\section{INTRODUCTION}

Medial antebrachial cutaneous nerve (MACN) provides sensory innervation to the skin of medial forearm. In the medial arm, it pierces the deep fascia to become subcutaneous and runs along the basilic vein (BV) to the elbow and forearm. Its anatomy is of clinical interest since local block can be employed in arteriovenous fistula surgery at forearm (Viscomi et al., 1996). Moreover, the MACN has been used as donor graft for repair of several injured nerves, for example, digital nerve (Nunley et al., 1989), facial nerve (Haller \& Shelton, 1997) and posterior interosseous nerve (Mokhtee et al., 2009). Due to the close proximity between the MACN and basilic vein (BV), the nerve is vulnerable to trauma caused by venipuncture (Horowitz, 1994; Horowitz, 2000). Therefore, precise knowledge in the anatomy of $\mathrm{MACN}$ is crucial for these procedures.
Several studies on the anatomy of MACN have been done. Masear et al. (1989) examined the vertical distance of the posterior branch of MACN to the medial epicondyle (ME). The vertical distance from the ME to the branching point of MACN was measured in one study (Race \& Saldana, 1991). The close anatomical relationship between the MACN and BV was also reported (Horowitz, 2000; Yamada et al., 2008). However, measurements among these structures especially in the horizontal plane have not been done. Regarding the MACN ramification, the exact number of branches has not been documented. This work was, therefore, aimed to examine the branching pattern and measure the distances from the MACN to the $\mathrm{ME}$ and $\mathrm{BV}$ along the interepicondylar line (IEL). Brachial artery, another palpable landmark in the living subjects, was also included for the measurement. 


\section{MATERIAL AND METHOD}

Ninety-six upper extremities from 48 formalin-fixed cadavers (26 males and 22 females) were included with an approval from the institutional ethics committee. All cadavers were in the anatomical position with the forearms supinated. The medial side of arm and cubital fossa was dissected to expose the MACN, BV and BA. Anatomical courses of the nerve and vein were carefully preserved. The most prominent points of the ME and lateral epicondyle (LE) were identified and the IEL located with silk thread passing these two landmarks. The course of MACN from its piercing point through the deep fascia to where the MACN crossed the IEL was followed. Number of MACN branches at the level of IEL was noted. Since there were more than 2 branches piercing the deep fascia and they were not followed into the forearm, these branches were not categorized into the anterior and posterior. However, for consistency among different branching patterns, the most medial branch was designated $\mathrm{Br} 1$ with the more lateral branch $\mathrm{Br} 2$ and so on.

To obtain quantitative data, a digital caliper was used to measure the distances from the midline of MACN to those of $\mathrm{BV}$ and $\mathrm{BA}$ including the most prominent point of $\mathrm{ME}$ along the IEL (Fig. 1). Student's t test was employed to detect any significant differences in the measurement data between sexes and sides. $\mathrm{p}<0.05$ was considered significant.
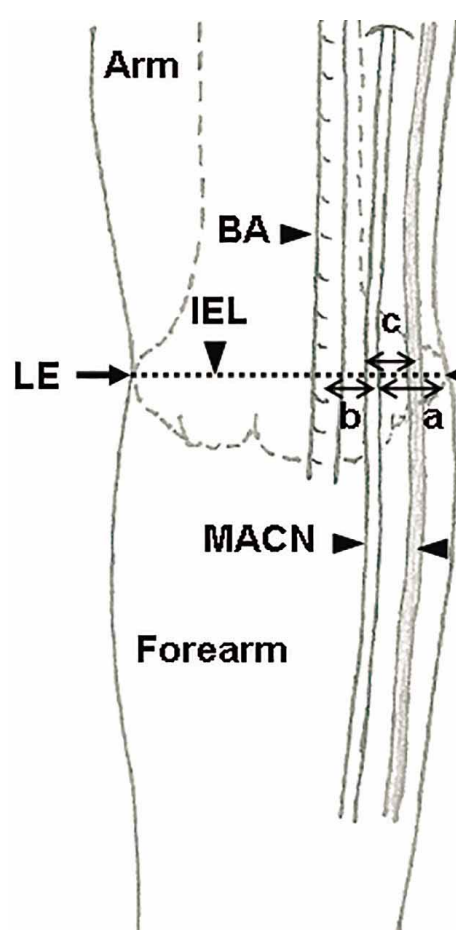

\section{ME} brachial artery, BV basilic vein.

\section{RESULTS}

The MACN most commonly emerged from the brachial fascia as two branches (50 specimens, 52.1\%) (Table I, Fig. 2B). Three-branch pattern was the next most common $(39.6 \%)$ with small number of specimens having no branch (2.1\%), 4 branches (5.2\%) and 5 branches (1.0\%) (Fig. 2). After becoming subcutaneous and coursing more distally, the MACN often ramified or, in some cases, gave no branches until reaching the level of IEL. Asymmetry in the branching pattern of MACN was observed in 13 males $(50.0 \%)$ and 11 females $(50.0 \%)$.

At the level of IEL, 2 branches of the MACN were observed in most cases (58 specimens, 60.4\%) (Table II). Decreasing number of specimens had 3 branches $(26.0 \%)$, no branch $(10.4 \%)$, and 4 branches $(3.1 \%)$. In case of no branching, the MACN passed the IEL approximately 1.5 $\mathrm{cm}$ in average from the ME and BA in both sexes (Table III). Concerning the $\mathrm{BV}$, most MACN were lateral to the $\mathrm{BV}$ at the level of IEL except one male arm. The distances to the $\mathrm{BV}$ were $0.6 \pm 0.9 \mathrm{~cm}$ (range, $0.0-2.1$ ) in male and $0.7 \pm 0.5 \mathrm{~cm}$ (range, $0.2-1.3$ ) in female. It is also worth noting that the MACN was directly superficial to the BV in one male specimen. No sex or side differences were observed in any measurement.

As for two branches, the medial branch of MACN (Br1) was $1.1 \pm 0.7 \mathrm{~cm}$ in male and $0.7 \pm 0.8 \mathrm{~cm}$ in female from the $\mathrm{ME}$ at the level of IEL with significant sex difference only on the left side $(\mathrm{p}<0.05)$ (Table IV). The distances between the lateral branch $(\mathrm{Br} 2)$ and $\mathrm{ME}$ were $2.5 \pm 0.9$ and $1.7 \pm 0.8 \mathrm{~cm}$ in male and female, respectively. These values were again significantly different between sexes $(\mathrm{p}<0.01$ left, $\mathrm{p}<0.05$ right). The distances from $\mathrm{Br} 1$ and $\mathrm{Br} 2$ to the $\mathrm{BA}$ were approximately 2 and $1 \mathrm{~cm}$, respectively, at the level of IEL in both sexes. These branches in 10 specimens (17.2\%) lay just superficial to the BA in the same position. To the $\mathrm{BV}, \mathrm{Br} 1$ was found within the distance of $1 \mathrm{~cm}$ in average at the level of IEL in both male and female. $\mathrm{Br} 2$ was $1.4 \pm 0.9 \mathrm{~cm}$ in male and $1.0 \pm 0.8 \mathrm{~cm}$ in female lateral to the BV. Similar to the BA, both Br1 and Br2 could be found over the BV. There were no side differences in any measurement. These measurement data are summarized in Figure 3.

Fig. 1. Measurements regarding the anatomy of medial antebrachial cutaneous nerve (MACN) done in this study. The right arm is shown. Distances were measured from the MACN to the ME (a), BA (b) and BV (c). LE lateral epicondyle, ME medial epicondyle, IEL interepicondylar line, BA 


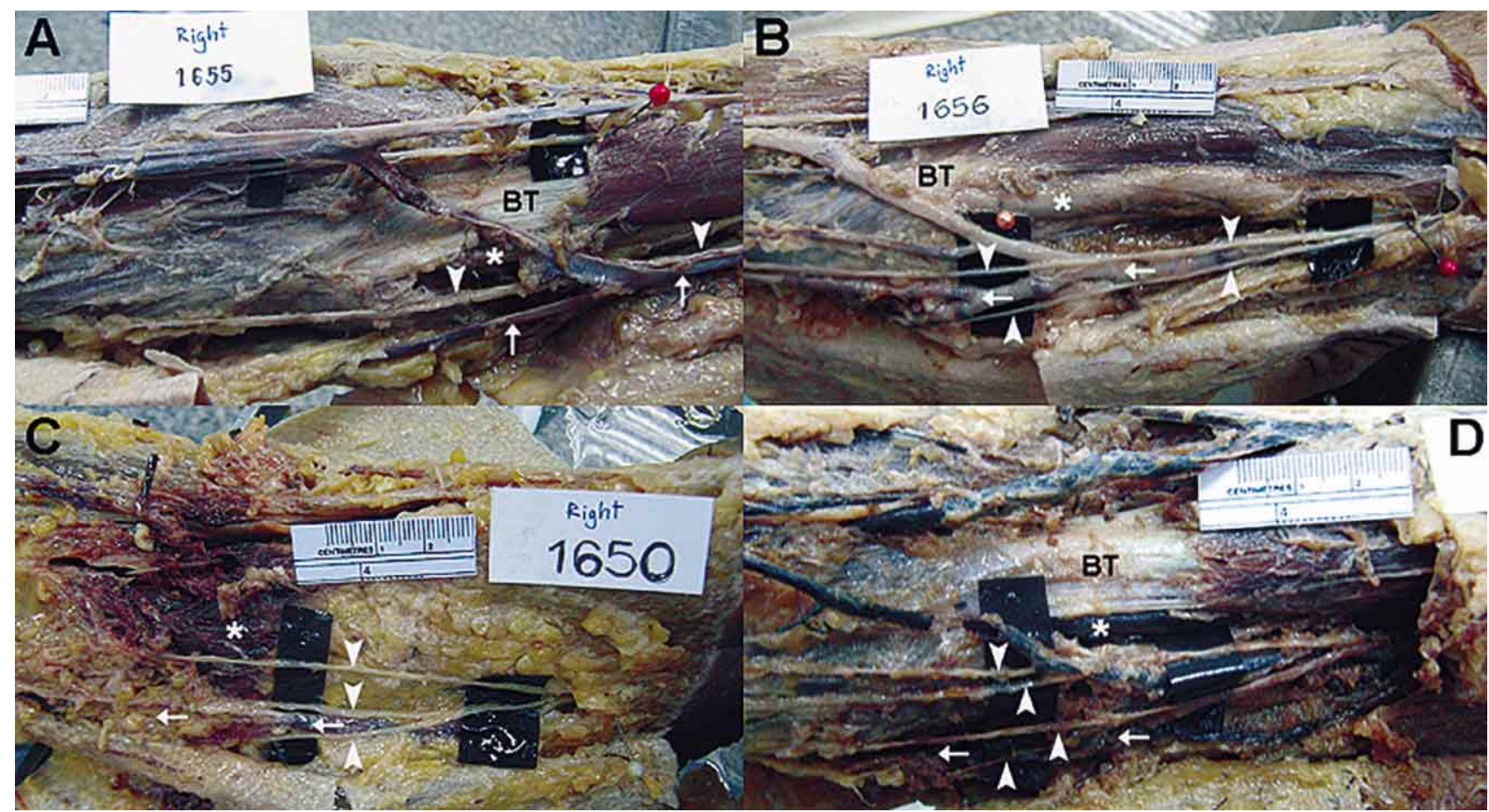

Fig. 2. Branching patterns of the medial antebrachial cutaneous nerve (MACN): single trunk (A), two branches (B), three branches (C) and four branches (D). Arrows indicate the basilic vein whereas asterisks and arrowheads indicate the brachial artery and branches of the MACN, respectively. BT biceps brachii tendon.

Table I. Number of MACN branches emerging from the deep fascia.

\begin{tabular}{lcccccc}
\hline Sex & & \multicolumn{5}{c}{ Number of specimens } \\
& No branch & 2 branches & 3 branches & 4 branches & 5 branches & Total \\
\hline Male & $2(3.8 \%)$ & $28(53.8 \%)$ & $19(36.5 \%)$ & $2(3.8 \%)$ & $1(1.9 \%)$ & $52(100 \%)$ \\
Female & - & $22(50.0 \%)$ & $19(43.2 \%)$ & $3(6.8 \%)$ & - & $44(100 \%)$ \\
Total & $2(2.1 \%)$ & $50(52.1 \%)$ & $38(39.6 \%)$ & $5(5.2 \%)$ & $1(1.0 \%)$ & $96(100 \%)$ \\
\hline
\end{tabular}

Table II. Number of MACN branches at the level of interepicondylar line.

\begin{tabular}{lllccr}
\hline Sex & & \multicolumn{3}{c}{ Number of specimens } \\
& No branch & 2 branches & 3 branches & 4 branches & Total \\
\hline Male & $6(11.5 \%)$ & $29(55.8 \%)$ & $14(26.9 \%)$ & $3(5.8 \%)$ & $52(100 \%)$ \\
Female & $4(9.1 \%)$ & $29(65.9 \%)$ & $11(25.0 \%)$ & - & $44(100 \%)$ \\
Total & $10(10.4 \%)$ & $58(60.4 \%)$ & $25(26.0 \%)$ & $3(3.1 \%)$ & $96(100 \%)$ \\
\hline
\end{tabular}

Table III. Measurement data of MACN in case of no branching.

\begin{tabular}{|c|c|c|}
\hline \multirow{2}{*}{$\begin{array}{l}\text { Measurement } \\
* \text { from one specimen }\end{array}$} & \multicolumn{2}{|c|}{ Distance (cm) (Range) } \\
\hline & Male & Female \\
\hline MACN - MEat IEL & $1.5 \pm 0.8(0.4-2.5)$ & $1.5 \pm 1.1(0.6-2.9)$ \\
\hline MACN - BA at IEL & $1.5 \pm 0.9(0.4-2.6)$ & $1.6 \pm 0.5(1.1-2.1)$ \\
\hline MACN - BV at IEL & -- & -- \\
\hline - MACN medial to BV & $1.5^{*}$ & - \\
\hline - MACN lateral to BV & $0.6 \pm 0.9(0.0-2.1)$ & $0.7 \pm 0.5(0.2-1.3)$ \\
\hline
\end{tabular}

Data are means \pm SD

IEL interepicondylar line, ME medial epicondyle, BV basilic vein, BA brachial artery 
In case of three branches, the measurement data are shown in Table V. Br1 was the closest to the ME and the farthest from the BA. The distances to the ME tended to be longer in male than in female with significant difference in case of $\mathrm{Br} 3(\mathrm{p}<0.05)$. It should be noted that $\mathrm{Br} 1$ and $\mathrm{Br} 3$ were found over the $\mathrm{ME}$ and $\mathrm{BA}$ in $8(33.3 \%)$ and 1 (4.2\%) specimens, respectively. Br1 and $\mathrm{Br} 2$ were within $1 \mathrm{~cm}$ in average away from the BV. In $5(20.8 \%)$ and 1 (4.2\%) specimens, Br1 and Br2 lay over the BV, respectively. Br3 was approximately $1.5 \mathrm{~cm}$ in average far from the BV. Significant differences between sides were not observed.

Four-branch pattern was found in only 3 male specimens. The distances from the MACN to the ME varied from 0 to $3.2 \mathrm{~cm}$. In case of the $\mathrm{BA}$, the range of distances was $0.7-3.9 \mathrm{~cm}$. The MACN could be found at $0.3-2.3$ $\mathrm{cm}$ lateral to the $\mathrm{BV}$.

Table IV. Measurement data of MACN in case of 2 branches.

\begin{tabular}{|c|c|c|c|c|c|c|c|}
\hline \multirow[t]{3}{*}{ Sex } & \multirow[t]{3}{*}{ Side } & \multicolumn{6}{|c|}{ Distance (cm) (Range) } \\
\hline & & \multicolumn{2}{|c|}{ MACN - ME at IEL } & \multicolumn{2}{|c|}{ MACN - BA at IEL } & \multicolumn{2}{|c|}{ MACN - BV at IEL } \\
\hline & & Br1 & Br2 & Br1 & Br2 & Br1 & Br2 \\
\hline \multirow[t]{6}{*}{ Male } & Left & $1.2 \pm 0.6 \mathrm{a}$ & $2.4 \pm 0.9^{\mathrm{b}}$ & $2.2 \pm 0.6$ & $1.1 \pm 0.5$ & $0.5 \pm 0.2^{\mathrm{m}}$ & $1.6 \pm 1.01^{\mathrm{a}}$ \\
\hline & & & & & & $0.9 \pm 0.4^{1}$ & \\
\hline & Right & $1.1 \pm 0.8$ & $2.6 \pm 0.9^{\mathrm{a}}$ & $2.3 \pm 1.0$ & $0.9 \pm 0.6$ & $0.7 \pm 0.3^{\mathrm{m}}$ & $1.2 \pm 0.71$ \\
\hline & Bilateral & $1.1 \pm 0.7$ & & $2.3 \pm 0.9$ & $1.0 \pm 0.6$ & $0.7 \pm 0.6^{1}$ & \\
\hline & & $(0.3-3.0)$ & $2.5 \pm 0.9$ & $(0.0-4.1)$ & $(0.0-2.4)$ & $0.6 \pm 0.3^{\mathrm{m}}$ & $1.4 \pm 0.91$ \\
\hline & & & $(1.2-4.1)$ & & & $\begin{array}{l}0.9 \pm 0.4^{1} \\
(0.0-3.4)\end{array}$ & $(0.0-3.5)$ \\
\hline \multirow[t]{6}{*}{ Female } & Left & $0.6 \pm 0.7$ & $1.6 \pm 0.7$ & $2.1 \pm 0.6$ & $1.2 \pm 0.4$ & $0.6 \pm 0.3^{\mathrm{m}}$ & $0.9 \pm 0.61$ \\
\hline & & & & & & $0.4 \pm 0.3^{1}$ & \\
\hline & Right & $0.8 \pm 1.0$ & $1.8 \pm 1.0$ & $2.0 \pm 0.6$ & $1.0 \pm 0.6$ & $0.8 \pm 0.4^{\mathrm{m}}$ & $1.0 \pm 0.91$ \\
\hline & & & & & & $0.9 \pm 0.4^{1}$ & \\
\hline & Bilateral & $0.7 \pm 0.8$ & $1.7 \pm 0.8$ & $2.0 \pm 0.6$ & $1.1 \pm 0.5$ & $0.7 \pm 0.3^{\mathrm{m}}$ & $1.0 \pm 0.81$ \\
\hline & & $(0.0-2.9)$ & $(0.6-4.2)$ & $(0.1-3.4)$ & $(0.0-2.1)$ & $\begin{array}{r}0.8 \pm 0.4^{1} \\
(0.0-1.5)\end{array}$ & $(0.0-2.9)$ \\
\hline
\end{tabular}

Data are means \pm SD IEL interepicondylar line, ME medial epicondyle, BV basilic vein, BA brachial artery, $\mathrm{Br} 1$ and $\mathrm{Br} 2$ the medial and lateral branches of MACN, respectively

$\mathrm{m}$ when $\mathrm{Br}$ was medial to $\mathrm{BV}, 1$ when $\mathrm{Br}$ was lateral to $\mathrm{BV}$, a $\mathrm{p}<0.05, \mathrm{~b} \mathrm{p}<0.01$ vs. female on the same side

Table V. Measurement data of MACN in case of 3 branches.

\begin{tabular}{|c|c|c|c|c|c|c|c|c|c|c|}
\hline \multirow[t]{3}{*}{ Sex } & \multirow[t]{3}{*}{ Side } & \multicolumn{9}{|c|}{ Distance $(\mathrm{cm})$ (Range) } \\
\hline & & \multicolumn{3}{|c|}{ MACN - ME at IEL } & \multicolumn{3}{|c|}{ MACN - BA at IEL } & \multicolumn{3}{|c|}{ MACN - BV at IEL } \\
\hline & & Br1 & $\mathrm{Br} 2$ & $\mathrm{Br} 3$ & Br1 & $\mathrm{Br} 2$ & $\mathrm{Br} 3$ & $\mathrm{Br} 1$ & $\mathrm{Br} 2$ & $\mathrm{Br} 3$ \\
\hline \multirow[t]{4}{*}{ Male } & Left & $0.6 \pm 0.6$ & $1.7 \pm 0.5$ & $2.7 \pm 0.5^{\mathrm{a}}$ & $3.3 \pm 0.8$ & $2.1 \pm 0.6$ & $1.1 \pm 0.5$ & $\begin{array}{l}0.9 \pm 0.4 \mathrm{~m} \\
0.0^{1 *}\end{array}$ & $\begin{array}{l}0.4 \pm 0.1^{\mathrm{m}} \\
0.8 \pm 0.4^{1}\end{array}$ & $1.5 \pm 0.71$ \\
\hline & Right & $0.5 \pm 0.5$ & $1.6 \pm 0.4$ & $2.9 \pm 0.7$ & $3.0 \pm 1.4$ & $2.3 \pm 0.6$ & $1.0 \pm 0.7$ & $\begin{array}{l}1.0 \pm 0.7 \mathrm{~m} \\
0.4^{1 *}\end{array}$ & $\begin{array}{l}0.3 \mathrm{~m}^{*} \\
0.7 \pm 0.2^{1}\end{array}$ & $1.4 \pm 1.01$ \\
\hline & Bilateral & $0.5 \pm 0.5$ & $1.7 \pm 0.5$ & $2.8 \pm 0.6$ & $3.1 \pm 1.1$ & $2.2 \pm 0.6$ & $1.1 \pm 0.6$ & $\begin{array}{l}0.9 \pm 0.6 \mathrm{~m} \\
0.4^{1 *}\end{array}$ & $0.4 \pm 0.1^{\mathrm{m}}$ & $\begin{array}{l}1.5 \pm 0.91 \\
(0.2-2.8)\end{array}$ \\
\hline & & $(0.0-1.5)$ & $(0.8-2.4)$ & $(1.8-3.7)$ & $(0.4-4.3)$ & $(1.4-3.3)$ & $(0.0-2.1)$ & $(0.0-2.0)$ & $\begin{array}{l}0.8 \pm 0.3^{1} \\
(0.0-1.3)\end{array}$ & \\
\hline \multirow[t]{4}{*}{ Female } & Left & $0.5 \pm 0.3$ & $1.1 \pm 0.5$ & $1.9 \pm 0.6$ & $2.9 \pm 0.6$ & $2.3 \pm 0.7$ & $1.5 \pm 0.7$ & $0.4^{\mathrm{m} *}$ & $0.8 \pm 0.4^{1}$ & $1.6 \pm 0.41$ \\
\hline & Right & $0.5 \pm 0.7$ & $1.3 \pm 0.7$ & $2.2 \pm 0.8$ & $2.7 \pm 0.6$ & $1.9 \pm 0.5$ & $1.0 \pm 0.5$ & $\begin{array}{l}0.6 \pm 0.1^{1} \\
0.4 \pm 0.1 \mathrm{~m} \\
0.9^{*}\end{array}$ & $0.7 \pm 0.4^{1}$ & $1.5 \pm 0.41$ \\
\hline & Bilateral & & & & & & & $0.4 \pm 0.1 \mathrm{~m}$ & $0.7 \pm 0.4^{1}$ & $1.6 \pm 0.41$ \\
\hline & & $\begin{array}{l}0.5 \pm 0.5 \\
(0.0-1.8)\end{array}$ & $\begin{array}{l}1.2 \pm 0.6 \\
(0.7-2.7)\end{array}$ & $\begin{array}{l}2.1 \pm 0.7 \\
(1.4-3.5)\end{array}$ & $\begin{array}{l}2.7 \pm 0.6 \\
(1.6-3.7)\end{array}$ & $\begin{array}{l}2.0 \pm 0.6 \\
(1.2-3.0)\end{array}$ & $\begin{array}{l}1.2 \pm 0.6 \\
(0.4-2.3)\end{array}$ & $\begin{array}{l}0.7 \pm 0.21 \\
(0.0-0.9)\end{array}$ & $(0.3-1.3)$ & $(0.9-2.1)$ \\
\hline
\end{tabular}

Data are means \pm SD $\quad$ IEL interepicondylar line, ME medial epicondyle, BV basilic vein, BA brachial artery, Br1, Br2 and Br3 the medial, middle and lateral branches of MACN, respectively

* from one specimen, $\mathrm{m}$ when $\mathrm{Br}$ was medial to $\mathrm{BV}, 1$ when $\mathrm{Br}$ was lateral to $\mathrm{BV}$, a $\mathrm{p}<0.05$ vs. female on the same side. 


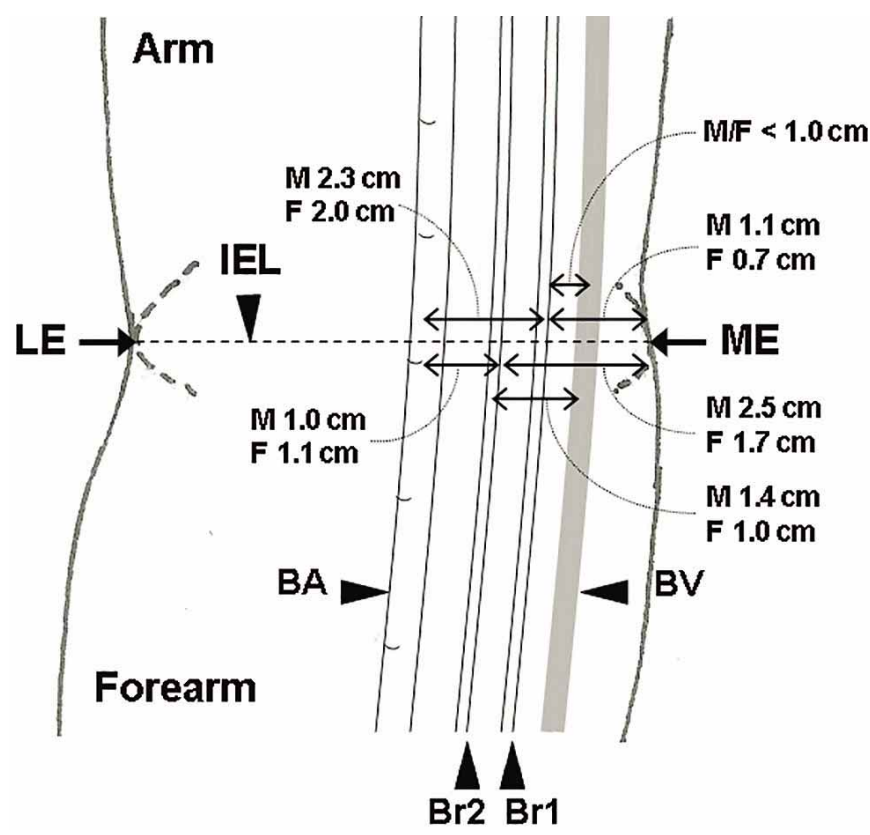

Fig. 3. Summary of distances from the medial antebrachial cutaneous nerve (MACN) to important landmarks in the most common branching pattern (two branches). Br1 and $\mathrm{Br} 2$ are medial and lateral branches of the MACN, respectively. LE lateral epicondyle, ME medial epicondyle, IEL interepicondylar line, BA brachial artery, BV basilic vein, M male, F female.

\section{DISCUSSION}

In this study, the MACN gave 2 branches before piercing the deep fascia of arm in about half of specimens (52.1\%). The MACN emerging as 3 branches was the next most common pattern $(39.6 \%)$. Other patterns were observed in less than $10 \%$. At the level of IEL, 2-branch and 3-branch were still the two most frequently found patterns ( $60.4 \%$ and $26.0 \%$, respectively). The number of MACN subcutaneous branches in the arm and cubital fossa is rarely reported. Most studies only mentioned the anterior and posterior branches. However, one study reported that the MACN gave 5-8 branches beginning $2 \mathrm{~cm}$ proximal to the ME (Race \& Saldana, 1991). The branches of MACN in these zones are clinically important as they are vulnerable to injuries induced by several procedures. In the arm, insertion and removal of hormonal contraceptive implant can cause MACN injury (Nash \& Staunton, 2001; Wechselberger et al., 2006). Injury of the posterior branch of MACN has been reported in patients undergoing cubital tunnel surgery (Lowe et al., 2004; Mackinnon \& Novak, 2007). Arthroscopy can also be associated with the MACN injury (Stothers et al., 1995; Kelly et al., 2001). Moreover, routine venipuncture in the cubital fossa and venous catheterization in the medial arm can be complicated by the MACN damage. This will be discussed in detail later. Our results further emphasize the vulnerability of MACN to these procedures since as many as 4 branches can be found in the subcutaneous layer of arm and cubital fossa.

To better localize the MACN branches in the cubital fossa, measurements related to the palpable landmarks (ME and BA) at the level of IEL were done. In addition, due to the close proximity between the $\mathrm{MACN}$ and BV, distances between these structures were also measured. Since the number of MACN branches was highly variable, measurement data were categorized into 4 groups: no branch, 2 branches, 3 branches and 4 branches. Due to highly variable distances from the MACN to the landmarks in these patterns, safe zone could not be established. However, important conclusions can be made. First, it was possible that one branch of MACN passed over or close (within $0.5 \mathrm{~cm}$ ) to the ME regardless of the branching pattern. Second, the MACN could be found directly superficial to the BA, especially when more than one branch of MACN was present (more than $80 \%$ of cases). Third, the MACN could run over or close to the BV either medially or laterally regardless of the number of branch. The MACN overlying the $\mathrm{BV}$ has been previously reported (Horowitz, 2000; Mikuni et al., 2013). Close relationship between the MACN to the BV and other cutaneous veins in the cubital fossa was also demonstrated (Yamada et al.; Mikuni et al.). Thus, our and other studies' data confirm the close proximity between the MACN and BV.

The above measurement data are of clinical interest. The ME and BA which can be localized by palpation, may be used to suggest the presence of MACN in vicinity. Hence, our data can facilitate medical procedures by either avoiding the MACN or localizing the MACN during anesthetic block and graft harvest. Given the proximity of the MACN to the ME, injuries to this nerve are common during the cubital tunnel surgery to release the ulnar nerve entrapment (Dellon \& Mackinnon, 1985; Sarris et al., 2002; Lowe et al.; Mackinnon \& Novak). Consistent with these reports, our findings emphasize the close proximity between the MACN and the ME independent of the total number of branches. The MACN block can be used to achieve sufficient anesthesia in forearm arteriovenous fistula surgery (Viscomi et al.). In addition, the MACN has long been used for repair of other nerves, for example, digital nerve (Nunley et al.), facial nerve (Haller \& Shelton) and posterior interosseous nerve (Mokhtee et al.). In case of the $\mathrm{BV}$, it is normally used for venipuncture and catheterization to monitor the central venous pressure. Venipuncture-associated causalgia resulting from the MACN injury has been reported (Horowitz, 1994, 2000). 
Therefore, the presence of MACN close to or even over the $\mathrm{BV}$ should be aware during the procedure.

It is worth noting that asymmetry in the branching pattern of MACN was observed in 50\% of both male and female. The high incidence may reflect the high variation of branching even in the same subject. This finding suggests that it is not always accurate to extrapolate the branching pattern from one side to the other. However, no significant differences in the measurement data were observed between sides. In contrast, significant sex differences were found in some parameters. In other measurements, distances in male tended to be longer than those of female. This was likely due to bigger specimens in male. Comparisons of these distances to the forearm length or width would exclude the size factor. However, we did not measure any of these forearm parameters. These differences between sexes should be kept in mind when applying the data to individual subject.
In conclusion, this study showed that 2- and 3-branch patterns of MACN were found in the majority of specimens. Descriptive and measurement data regarding the anatomy of MACN related to adjacent landmarks including the ME, $\mathrm{BA}$ and BV were also obtained. These data are useful for either avoiding the MACN injury or localizing the MACN during various procedures. However, high variation and asymmetry in the branching pattern including sex differences should be aware.

\section{ACKNOWLEDGEMENTS}

The authors would like to thank staffs in the cadaver unit, Department of Anatomy, Faculty of Medicine, especially Mr. Durongrit Sawangnetr, for facilitation during the dissection.

DAMWAN, A.; AGTHONG, S.; AMARASE, C.; YOTNUENGNIT, P.; HUANMANOP, T. \& CHENTANEZ, C. Nervio cutáneo antebraquial medial: relación anatómica con el epicóndilo medial, vena basílica y arteria braquial. Int. J. Morphol., 32(2):481-487, 2014.

RESUMEN: El recorrido del nervio cutáneo antebraquial medial (NCAM) proporciona la inervación sensorial medial del antebrazo. Su anatomía se ha descrito en parte, porque los datos relativos a su patrón de ramificación y distancias a puntos de referencia adyacentes son insuficientes. El propósito de este estudio fue proporcionar datos morfométricos sobre la anatomía del NCAM, comparando entre lados y sexos. Se disecaron 96 miembros superiores de 26 hombres y 22 mujeres. Se encontró que 5 ramos del NCAM traspasaron la fascia profunda y llegaron 4 hasta la línea interepicondylar (LIE). Presencia de 2 y 3 ramos se encontró en la mayoría de los casos (>80\%). Las distancias de estos ramos a los puntos anatómicos variaron considerablemente. En caso de ausencia de ramos, la distancia medial al epicóndilo medial $(\mathrm{EM})$ y arteria braquial $(\mathrm{AB})$ fueron de aproximadamente $1,5 \mathrm{~cm}$, mientras que a la vena basílica (VB) fueron $0,7 \mathrm{~cm}$ en ambos sexos. Independientemente del patrón de ramificación, el NCAM podría pasar sobre o cerca (a menos de $0,5 \mathrm{~cm}$ ) del EM, VB y AB. Asimetría en el patrón de ramificación se encontró en $50 \%$ de las muestras. Diferencias en algunos de los parámetros de medición se observaron según sexo, pero no por lado. Estos datos son relevantes para localizar el NCAM durante el bloqueo del nervio y la toma de injertos, sino también para evitar la lesión del nervio durante los procedimientos quirúrgicos.

PALABRAS CLAVE: Nervio cutáneo antebraquial medial; Anatomía; Epicóndilo medial; Vena basílica; Arteria braquial.

\section{REFERENCES}

Dellon, A. L. \& MacKinnon, S. E. Injury to the medial antebrachial cutaneous nerve during cubital tunnel surgery. J. Hand Surg. Br., 10(1):33-6, 1985.

Haller, J. R. \& Shelton, C. Medial antebrachial cutaneous nerve: a new donor graft for repair of facial nerve defects at the skull base. Laryngoscope, 107(8):1048-52, 1997.

Horowitz, S. H. Peripheral nerve injury and causalgia secondary to routine venipuncture. Neurology, 44(5):962-4, 1994.

Horowitz, S. H. Venipuncture-induced causalgia: anatomic relations of upper extremity superficial veins and nerves, and clinical considerations. Transfusion, 40(9):1036-40, 2000.
Kelly, E. W.; Morrey, B. F. \& O'Driscoll, S. W. Complications of elbow arthroscopy. J. Bone Joint Surg. Am., 83-A(1):25-34, 2001.

Lowe, J. B. 3rd; Maggi, S. P. \& Mackinnon, S. E. The position of crossing branches of the medial antebrachial cutaneous nerve during cubital tunnel surgery in humans. Plast. Reconstr. Surg., 114(3):692-6, 2004.

Mackinnon, S. E. \& Novak, C. B. Operative findings in reoperation of patients with cubital tunnel syndrome. Hand (N. Y.), 2(3):137-43, 2007.

Masear, V. R.; Meyer, R. D. \& Pichora, D. R. Surgical anatomy of 
DAMWAN, A.; AGTHONG, S.; AMARASE, C.; YOTNUENGNIT, P.; HUANMANOP, T. \& CHENTANEZ, C. Medial antebrachial cutaneous nerve: anatomical relationship with the medial epicondyle, basilic vein and brachial artery. Int. J. Morphol., 32(2):481-487, 2014

the medial antebrachial cutaneous nerve. J. Hand Surg. Am., 14(2 Pt. 1):267-71, 1989.

Mikuni, Y.; Chiba, S. \& Tonosaki, Y. Topographical anatomy of superficial veins, cutaneous nerves, and arteries at venipuncture sites in the cubital fossa. Anat. Sci. Int., 88(1):46-57, 2013.

Mokhtee, D. B.; Brown, J. M.; Mackinnon, S. E. \& Tung, T. H. Reconstruction of posterior interosseous nerve injury following biceps tendon repair: case report and cadaveric study. Hand (N. Y.), 4(2):134-9, 2009.

Nash, C. \& Staunton, T. Focal brachial cutaneous neuropathy associated with Norplant use: suggests careful consideration of the recommended site for inserting contraceptive implants. J. Fam. Plann. Reprod. Health Care, 27(3):155-6, 2001.

Nunley, J. A.; Ugino, M. R.; Goldner, R. D.; Regan, N. \& Urbaniak, J. R. Use of the anterior branch of the medial antebrachial cutaneous nerve as a graft for the repair of defects of the digital nerve. J. Bone Joint Surg. Am., 71(4):563-7, 1989.

Race, C. M. \& Saldana, M. J. Anatomic course of the medial cutaneous nerves of the arm. J. Hand Surg. Am., 16(1):48-52, 1991.

Sarris, I.; Göbel, F.; Gainer, M.; Vardakas, D. G.; Vogt, M. T. \& Sotereanos, D. G. Medial brachial and antebrachial cutaneous nerve injuries: effect on outcome in revision cubital tunnel surgery. J. Reconstr. Microsurg., 18(8):665-70, 2002.

Stothers, K.; Day, B. \& Regan, W. R. Arthroscopy of the elbow: anatomy, portal sites, and a description of the proximal lateral portal. Arthroscopy, 11(4):449-57, 1995.

Viscomi, C. M.; Reese, J. \& Rathmell, J. P. Medial and lateral antebrachial cutaneous nerve blocks: an easily learned regional anesthetic for forearm arteriovenous fistula surgery. Reg. Anesth., 21(1):2-5, 1996.

Wechselberger, G.; Wolfram, D.; Pülzl, P.; Soelder, E. \& Schoeller, T. Nerve injury caused by removal of an implantable hormonal contraceptive. Am. J. Obstet. Gynecol., 195(1):323-6, 2006.

Yamada, K.; Yamada, K.; Katsuda, I. \& Hida, T. Cubital fossa venipuncture sites based on anatomical variations and relationships of cutaneous veins and nerves. Clin. Anat., 21(4):307-13, 2008.

\author{
Correspondence to: \\ Dr. Sithiporn Agthong \\ Department of Anatomy, Faculty of Medicine \\ Chulalongkorn University \\ Rama IV Road, Pathumwan, Bangkok, 10330 \\ THAILAND
}

\author{
Email: sagthong@hotmail.com
}

Received: 07-08-2013

Accepted: 11-04-2014 